Click www.researchjournal.co.in/online/subdetail.html to purchase.

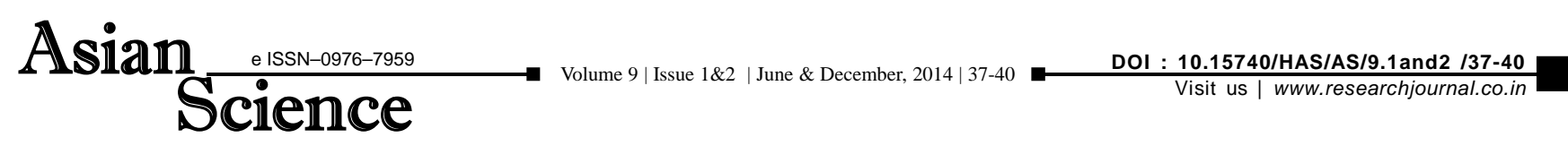

RESEARCH PAPER

\title{
Socio-economic profile of women in panchayat
}

\author{
SEEMAPRAKALPA* AND SURABHI MISHRA \\ Department of Home Science Extension, Kr. R.C.M.P.G. College (BRAU) MAINPURI (U.P.) INDIA
}

\begin{abstract}
Panchayat raj institution is a network of village panchayats. Representation of women in Panchayat was initiated to provide equal opportunities in political system at grass root level and as a result they rose up to national level. They could do better for their category from lower to upper level. So the aim of present study was to identify socio-economic profile of 60 women Panchayat functionaries. For assessing socio-economic profile of women functionaries, scale of Trivedi (1963) was used with slight modification. Interview schedule was used to collect primary data. The findings of the study show that they were in the age group of 31-40 years, backward caste, hindu, illiterate and educated upto Junior high school, married and from agricultural background, belonged to nuclear families having upto five members. Their annual income was in between Rs.10, 001-Rs.20, 000. They were holding land size upto 2.5 acre and residing in kachcha house. Along with above betterment, they were facing various types of problems namely; problems regarding child rearing practices, social co-operation, and illiteracy. The findings of this study inform about the factual of their knowledge and they are required for make a mark of their thumb on papers besides it nothing. So, there is a need to aware women about their existence as an independent, their role, and responsibilities before giving them administrative incentives, because in this condition, they will not act as required but they will become the puppet of puppeteer.
\end{abstract}

Key Words : Women, Panchayat, Socio-economic characteristics

View point paper : Seemaprakalpa and Mishra, Surabhi (2014). Socio-economic profile of women in panchayat. Asian Sci., 9 (1\&2): 37-40.

\footnotetext{
* Author for correspondence

Seemaprakalpa, Department of Home Science Extension Education, Institute of Home Science, Dr. B.R. Ambedkar University, AGRA(U.P.) INDIA (Email: prakalpass@gmail.com)
} 